\title{
Material waste minimization techniques in building construction projects
}

\author{
Shitaw Tafesse* \\ Dilla University, Engineering and Technology College, Department of Construction \\ Technology and Management, Dilla, PO Box 419, Ethiopia
}

\begin{abstract}
In Ethiopia, the rapid expansion of the construction sector has resulted in the wastage of construction materials that negatively affect the environment, society, and the economy. The reason is inefficient waste management strategies practiced in construction projects. Hence, an adequate material waste management strategy is required. This study was an attempt to identify the key techniques that can help to minimize material wastage in building construction projects. Questionnaire surveys, interviews, and reviews of previous studies and related literature were employed in gathering the relevant data. Seventy of 85 questionnaires administered and distributed to contractors, consultants, and clients were returned. These data were analyzed using the relative importance index method. The results indicated that employing waste management officers for this purpose, using prefabricated or off-site production of components, appropriate on-site waste management, and incorporating a policy of material waste minimization plan were identified as key measures to minimize construction material wastes.
\end{abstract}

Keywords: Building construction; Construction material, Material wastes, Waste minimization

DOI: https://dx.doi.org/10.4314/ejst.v14i1.1

\section{INTRODUCTION}

The construction sector is very important for the development of every country. Its contribution to economic growth and long-term national development is widely acknowledged, highlighting its importance, particularly to developing countries (Ofori, 2015). The role of construction in socio-economic development goes beyond its share in national output (Lopes et al., 2011). Akadiri et al. (2012) states that the building sector is an essential part of every economy. The role that

\footnotetext{
* Corresponding author: shitu.taf@gmail.com

(C) This is an Open Access article distributed under the terms of the Creative Commons Attribution License (http://creativecommons.org/licenses/CC BY4.0)
} 
the sector plays in Ethiopia is very important. It creates business opportunity for construction firms, creates job opportunities for the community, and contributes to the economy of the country (CSA, 2011). It also contributes for the growth of a country by providing building infrastructure (Papargyropoulou et al., 2011). Despite these contributions, the rapid boom in construction has led to increasing construction wastes in developing countries (Muhammad et al., 2020).

Resource management is one of the biggest challenges in the performance of the Ethiopian construction sector (Tadesse Ayalew et al., 2016). Most sectors consume material resources more than the amount originally calculated. If the material waste is not properly handled and managed on the project site, this will lead to financial crises, and eventually negatively impact the community and the environment. The construction sector produces huge waste leading to environmental contamination and $\mathrm{CO}_{2}$ emissions (Ajayi et al., 2015). Inappropriate material management causes waste and results in environmental damage and financial loss during the various construction stages (Wahab and Lawal, 2011; Dajadian and Koch, 2014). For instance, Enshassi et al. (2006) claimed that it is one of the major causes of building stakeholder's business failure in developing countries. The total cost overrun due to construction waste is $30 \%$ of the cost of materials (Olusanjo et al., 2014; Eze et al., 2016). Depending on the material type, 8.5 to $16.6 \%$ of the materials was recorded as wastage (Adewuyi and Odesola, 2016).

Firm commitment to sustainable construction and environmental management helps reduce material wastage on a project (Adewuyi and Odesola, 2016). Waste reduction increases overall net income and helps achieve economic stability (Husnain et al., 2017). Minimizing and managing waste at construction site saves the cost of disposal and transport, increases profits, saves time, protects the environment, and creates clean and safe work sites (Eze et al., 2016). The need to prevent and reduce the volume of waste generated by the industry has encouraged a variety of research and policy formulations (Ajayi et al., 2017). Low and middle-income countries lag in research related to waste management in construction sites (Abarca-Guerrero et al., 2017). As a result, different strategies for minimizing construction wastes are considered essential for reducing construction waste. Few studies are available in developing countries, particularly in low-income countries. Research related to this discipline has not yet been widely published in Ethiopia. Construction has increased in Ethiopia, but there are no effective waste management systems in place to prevent waste (Endale Teferi, 2017); this has inhibited the development of key waste management strategies (Asmara Seyoum, 2015). In this regard, construction 
stakeholders have failed to implement good waste reduction strategies. Various types of material are leftover on-site, sent to landfills, and used for other purposes rather than their intended function.

Therefore, the overall aim of the current study was to determine the most important strategies capable of preventing and reducing material wastage in construction project sites. The study was designed and executed to identify adequate strategies for construction waste reduction, to analyze the perception of building project stakeholders on waste minimization techniques, and to confirm the key techniques to reduce construction wastes in building construction sites. Consequently, the study would assist construction stakeholders and other construction experts to understand key techniques that are required to minimize material wastes generated by construction activities, and maintain cleaner environment, and then minimize project costs.

\section{Material wastes and reduction strategies}

The construction sector is the largest waste generator to landfilling sites and at the same time the heavy consumer of resources. Previous studies have shown that building construction consumes $40 \%$ of the global energy, contributes 5$15 \%$ of the GDP, and provides 5-10\% of employment (DTIE, 2009); similarly, it consumes $40 \%$ of the world's raw materials (Sharma et al., 2011). It is also reported that construction waste accounts for $40 \%$ of total solid waste generated in Canada, 35\% in Brazil, and 65\% in Hong Kong (Esinn and Cosgun, 2007; Kofoworola and Gheewala, 2009; Solis-Guzman et al., 2009). The amount of waste generated from construction sites may vary from one sector to another and may depend on material type. For example, according to Bekr (2014), the mean percentage of wastage of materials indicates $21 \%$ sand, $20.7 \%$ aggregate, $19.6 \%$ PVC water pipes, $19.5 \%$ timber for formworks, $8.3 \%$ cement, $17.1 \%$ concrete block, $17 \%$ steel reinforcement, $16.8 \%$ concrete, $15.6 \%$ ceramic tiles, and $14.1 \%$ facing stones. Waste generation varies with the type of material such as bricks (2-12\%), wood (2-15\%), and plain cement concrete (1-10\%) (Husnain et al., $2017)$, on average bricks, are the most wasted material at a rate of $(6.82 \%)$, followed by tiles $(6.68 \%)$ and mortar from plaster $(6.63 \%)$.

Evidence suggests that implementing different waste minimization strategies helps to improve sustainable construction and efficient environment (Adewuyi and Odesola, 2016). The waste management system on the project site helps to prevent and reduce waste generated on site. According to Ajayi et al. (2015), sorting and recycling, reusing, use of waste prediction tools, site waste 
management plan (SWMP), design for flexibility and deconstruction, waste efficient procurement, off-site construction, and legislation and tax measures are key measures for tackling the problem. Effective site management like material logistic management, waste segregation, maximization of material reuse, and contractual provision are crucial strategies in reducing the quantity of material sent to landfills (Ajayi et al., 2017). Adewuyi and Odesola (2016) identified training and retraining of supervisors on material waste minimization strategies, use of modular design system, introducing incentives to motivate labor to minimize material wastage on site, purchasing raw materials that are just sufficient, and training and retraining of personnel on handling, storage, and transportation are the top-ranked strategies in managing construction wastes. In addition, improving awareness and education of the workforce regarding construction waste management, the practice of using offsite products and components, establishing waste management techniques for specific materials, standardization of design and material, and proper handling of construction materials are very important to achieve on-site waste minimization (Muhammad et al., 2020).

As suggested by Lemlem Temesgen (2016), checking materials supplied for the right quantities, proper storage, accurate specifications of materials, change of attitude of workers towards the handling of materials, assigning waste management officer are the most important measures used to mitigate material wastes. The quantity of material wasted could be reduced by implementing particular strategies for each of the construction materials. As recommended by Asmara Seyoum (2015), wastage of blocks is reduced by "stacking on pallets or level grounds and storing in a container or a covered place" and for the aggregate, "storing in separate bunkers and open stockpiles. On the other hand, waste of concrete making material is reduced by using ready mix concrete, transporting through pulleys and cranes, proper storage of material, improving site facilities, assigning skilled personnel, using proper formwork, and purchasing material from approved suppliers (Amsale Markos, 2017). Employing skilled cutters, storing steel reinforcement properly to avoid rusting is a potential measure to reduce wastage of reinforcement ( $\mathrm{Lu}$ et al., 2011) while improving the performance of formwork construction helps to reduce the most source of concrete waste. 


\section{RESEARCH METHODS}

Based on the aim of the study, which sought to develop a holistic approach to minimize material waste, a combination of qualitative and quantitative methods was adopted. Depending on field studies of building construction sites, which includes an in-depth interview with individual participants, and focus group discussion, different waste reduction techniques have been identified. In addition, literature in the area of the existing construction waste reduction strategy was reviewed. The techniques were then put into a questionnaire survey to explore their generalizability.

\section{Data collection}

While carrying out qualitative data collection, an in-depth interview was conducted on individual participants or multiple participants (Creswell, 2013). Individuals were interviewed and focus group discussion was conducted in this study. A total of six construction sites in Addis Ababa, Ethiopia, were selected for this study. The method was used to explore subjective information from the participants on the current practice of waste reduction strategies, in addition to a review of previous studies. Table 1 shows 25 practices that were found to be capable of reducing material waste from literature, while the remaining techniques included in the data analysis of this study were collected through interviews and discussions.

Table 1. Material waste minimization strategies identified from the literature

\begin{tabular}{|c|c|}
\hline Material waste minimization techniques & References \\
\hline Design a standardized material dimension & $\begin{array}{l}\text { Dainty and Brooke (2004); Osmani et } \\
\text { al. (2008) }\end{array}$ \\
\hline $\begin{array}{l}\text { Design adequate building component size, } \\
\text { regular shape, and spacing }\end{array}$ & Adewuyi and Odesola (2016) \\
\hline Avoid late design variation & $\begin{array}{l}\text { Osmani et al. (2008); Adewuyi and } \\
\text { Odesola (2016) }\end{array}$ \\
\hline $\begin{array}{l}\text { Accurate specifications and quantity of } \\
\text { materials }\end{array}$ & $\begin{array}{l}\text { Ajayi and Oyedele (2018); Daoud et } \\
\text { al. (2018) }\end{array}$ \\
\hline $\begin{array}{l}\text { Deliver the required quantity of material } \\
\text { based on schedule }\end{array}$ & $\begin{array}{l}\text { Ajayi et al. (2017; Muhammad et al. } \\
(2020)\end{array}$ \\
\hline $\begin{array}{l}\text { Purchase material that complies with the } \\
\text { specification }\end{array}$ & Ajayi and Oyedele (2018) \\
\hline Proper procurement management system & Endale Teferi (2017) \\
\hline Identify and select the right suppliers & Aparna (2017) \\
\hline Proper storage of material & $\begin{array}{l}\text { Sasidharani and Jayanthi (2015); } \\
\text { Aparna (2017) }\end{array}$ \\
\hline
\end{tabular}


Train workers about how to handle and install the material

Accurate inventory control

Carefully handle materials during work

Mechanical handling of materials

Use adequate tools and equipment

Use prefabricated or off-site produced components

Adopt recycling technology to recycle waste materials left over on-site

Adopt emerging or the latest technology product

Employ material waste management officer

Incorporate policy of material waste minimization plan

Establish strategies and guidelines for the use of recycled material Government environmental regulation

Appropriate waste management on site

Provide incentives to motivate personnel to minimize material wastage

Use software for material planning and scheduling

Properly inspect and check the quality of materials on site

Re-use leftover material on the site Improve the coordination among stakeholders

Record and measure different volume or quantity of waste
Adewuyi and Odesola (2016); Endale Teferi (2017)

Assem and Karima (2011)

Dania et al. (2007); Ajayi et al. (2017)

Assem and Karima (2011);

Muhammad et al. (2020)

Eze et al. (2016)

Franco and Herbert (2017);

Muhammad et al. (2020)

Franco and Herbert (2017)

Osmani et al. (2008)

Assem and Karima (2011);

Sasidharani and Jayanthi (2015)

Adewuyi and Odesola (2016);

Muhammad et al. (2020)

Dania et al. (2007)

Dania et al. (2007)

Ali et al. (2019)

Muhammad et al. (2020)

Aparna (2017)

Aparna (2017)

Dania et al. (2007); Ali et al. (2019)

Asmara Seyoum (2015)

Assem and Karima (2011)

\section{Classification of waste minimization strategies}

Material waste originates from a variety of sources and appropriate strategies to reduce it vary according to the source of the waste. For example, Roseline et al. (2016) classified the source of construction waste as design, procurement, material handling, and construction stage. Factors that lead to the generation of material wastes are classified as design and documentation, operational, procurement, materials storage, and handling (Agyekum et al., 2013). In this regard, waste reduction strategy should be developed for each major causative factor. This approach was adopted in the present study. The strategies identified were classified based on their relevance in controlling and mitigating the source 
of wastes. In general, after a detailed review of the previous studies on the source of waste the following 1-4 $4^{\text {th }}$ major categories of material waste reduction strategies were developed and the remaining $5-6^{\text {th }}$ strategies (technology and legal or policy-related techniques) were found during the interview and focused group discussions. For example, design and documentation related strategies help to reduce the generation of material wastage in which their origin is due to design and documentation issues and procurement-related material wastes reduction strategy helps to control the occurrence of material waste due to material procurement and the same is done for the rest of strategies. For this study, six major categories of construction waste reduction strategies were developed, i.e., design and documentation, procurement, material storage and handling, planning and site management, technology, and legal or policy-related techniques.

\section{Questionnaire survey}

The sets of measures identified from the interview, group discussion, and literature review were operationalized into a questionnaire survey. This approach helped to reach a large audience through standardized means of data collection, thereby helping to make research findings more generalizable (Creswell, 2013). Using questionnaires, we systematically compile questions that are submitted to a sample of the population from which information is desired (Prabhat and Meenu, 2015). The validity of these measures identified was ensured by a pilot study. Ten experienced respondents participated in the pilot study. Out of 10 questionnaires, eight were received and checked for consistency. The questionnaire was then modified in light of the drawbacks and weaknesses encountered at this stage. The improved questionnaire, which served as means of data collection, consisted of 49 factors on a Likert scale of 1-5, where 1 stands for "very low importance" and 5 "very high importance". Finally, it was distributed to contractors, consultants, and clients using purposive sampling. Purposive sampling was adopted because it was used to identify information-rich participants whose understanding was important for the study (Creswell, 2013). The selection criteria of respondents were job position, experience, availability, and convenience to participate in the survey.

\section{Questionnaire rate of return}

For the preparation of comprehensive analysis, eighty-five (85) questionnaires were distributed to the selected respondents involved in building construction projects, i.e., 40 to the contractor, 30 to the consultant, and 15 to the clients who 
were available and willing to fill the questionnaires. Out of the distributed questionnaires, $70(81.67 \%)$ were fully completed and were received for data analysis. Figure 1 shows the number of questionnaires distributed and the rate of return from each stakeholder.

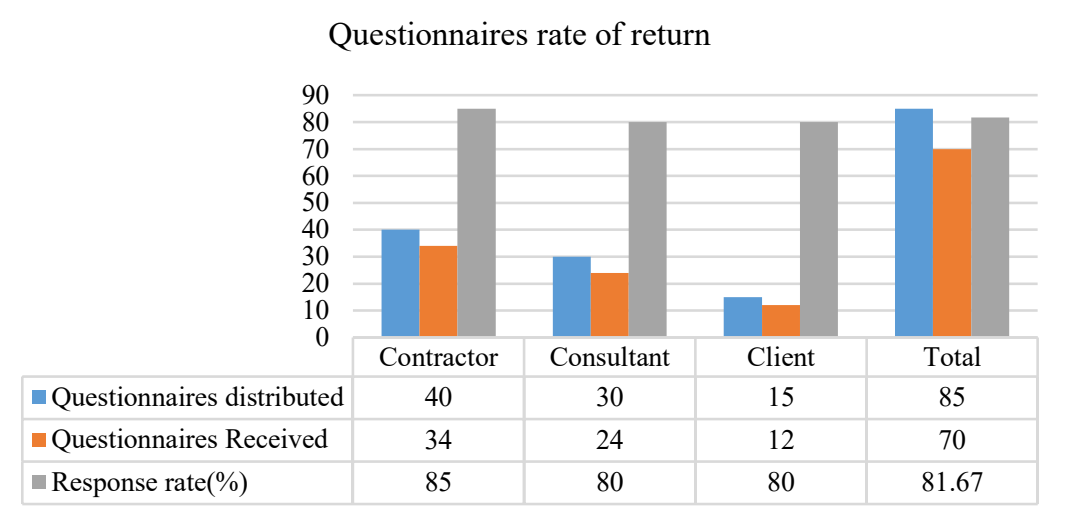

Figure 1. Rate of the response of the distributed questionnaire

\section{Data analysis}

As a means of establishing the key construction waste reduction measures for waste mitigation, the ranking and analysis were made based on the relative importance index of the Likert scale. Relative importance index (RII) was used for generating an index and used to show the level as perceived by research participants (Holt, 2014; Wahab and Lawal, 2011). To determine the relative ranking of factors, the scores were transformed into important indices based on the following equation (Tam, 2007);

$$
\mathrm{RII}=\frac{\sum W}{A * N}
$$

where $w$ is the weighting given to each factor by the respondent, ranging from 1 to 5 in which ' 1 ' is very low importance and ' 5 ' is very high importance; $A$ is the highest weight, in this study $A=5 ; N$ is the total number of samples, 70 for this study, and RII the relative important index, $0 \leq \mathrm{RII} \leq 1$. 


\section{RESULTS AND DISCUSSION}

The main strategies for the reduction of material waste from each category were identified based on the ranks made according to the results of the RII.

\section{Key material waste minimization techniques}

\section{Design and documentation}

Design and documentation are used to reduce the generation of waste materials in which their source is due to design and documentation issues. Minimizing construction waste at the design stage is commonly considered as a key strategy for effective waste minimization (Wang et al., 2014). Sixteen of them were categorized under this group as presented in Table 2.

Table 2. Design and documentation related minimization techniques of material waste

\begin{tabular}{|c|c|c|c|c|c|c|c|}
\hline Material waste minimization techniques & 1 & 2 & 3 & 4 & 5 & RII & Rank \\
\hline Design standardized material dimension & 6 & 7 & 9 & 15 & 33 & 0.777 & 1 \\
\hline Use experienced and sound design team & 4 & 7 & 10 & 22 & 27 & 0.774 & 2 \\
\hline $\begin{array}{l}\text { Design adequate building component } \\
\text { size, regular shape and spacing }\end{array}$ & 5 & 8 & 10 & 16 & 31 & 0.771 & 3 \\
\hline Avoid late design variation & 2 & 10 & 8 & 27 & 23 & 0.769 & 4 \\
\hline $\begin{array}{l}\text { Consider the environment during } \\
\text { designing }\end{array}$ & 5 & 7 & 12 & 17 & 29 & 0.766 & 5 \\
\hline $\begin{array}{l}\text { Design material optimization and } \\
\text { sustainability }\end{array}$ & 4 & 8 & 9 & 24 & 25 & 0.766 & 5 \\
\hline Design off-site construction & 3 & 8 & 15 & 16 & 28 & 0.766 & 5 \\
\hline Have accurate contract document & 6 & 6 & 10 & 22 & 26 & 0.760 & 6 \\
\hline $\begin{array}{l}\text { Accurate specification and quantity of } \\
\text { materials }\end{array}$ & 3 & 10 & 14 & 14 & 29 & 0.760 & 6 \\
\hline $\begin{array}{l}\text { Avoid designing for custom made size } \\
\text { as much as possible }\end{array}$ & 4 & 11 & 12 & 15 & 28 & 0.749 & 7 \\
\hline Simplified and proper details of drawing & 9 & 10 & 4 & 17 & 30 & 0.740 & 8 \\
\hline $\begin{array}{l}\text { Consider the availability of material } \\
\text { during designing }\end{array}$ & 3 & 11 & 17 & 19 & 20 & 0.720 & 9 \\
\hline Simple and repeatable design & 8 & 8 & 12 & 21 & 21 & 0.711 & 10 \\
\hline Reduce number of amenity areas & 10 & 8 & 14 & 21 & 17 & 0.677 & 11 \\
\hline $\begin{array}{l}\text { Amalgamate services adjacent to each } \\
\text { other }\end{array}$ & 7 & 13 & 19 & 15 & 16 & 0.657 & 12 \\
\hline $\begin{array}{l}\text { Design renewable resources as much as } \\
\text { possible }\end{array}$ & 13 & 12 & 15 & 19 & 11 & 0.609 & 13 \\
\hline
\end{tabular}


By using the relative importance index, designing for the standardized material dimension ( $\mathrm{RII}=0.777$ ) was found to be very important technique to reduce construction wastes. Considering this technique during the design phase helps to reduce the quantity of material that needs to be cut into pieces to match the real size of the building. This is supported by research conducted on critical management practices influencing on-site waste minimization in construction projects (Ajayi et al., 2017). Employing experienced and sound design team (RII $=0.774)$ significantly mitigated wastes by avoiding errors and omissions caused on the drawing due to the deficiency of experience of the designer. This measure plays a significant role in reducing material wastage (Adewuyi and Odesola, 2016). Designing for adequate building component sizes, regular shape, and spacing $(\mathrm{RII}=0.771)$ were also an important strategy to overcome material waste challenges. For example, Ajayi et al. ( 2015) claimed that optimized or standardized designs were critical approaches to achieve waste-free construction sites.

\section{Material procurement}

The possibility of preventing and reducing construction waste through the materials procurement process plays crucial role and needs to be practiced (Ajayi and Oyedele, 2018). Table 3 shows procurement-related strategies employed to control material wastage.

Table 3. Material procurement-related minimization techniques of material wastes

\begin{tabular}{|c|c|c|c|c|c|c|c|}
\hline Material waste minimization techniques & 1 & 2 & 3 & 4 & 5 & RII & Rank \\
\hline $\begin{array}{l}\text { Deliver required quantity of material based } \\
\text { on schedule }\end{array}$ & 4 & 6 & 14 & 17 & 29 & 0.774 & 1 \\
\hline $\begin{array}{l}\text { Purchase materials that comply with the } \\
\text { specification }\end{array}$ & 5 & 6 & 10 & 21 & 28 & 0.774 & 1 \\
\hline & 4 & 6 & 12 & 22 & 26 & 0.771 & 2 \\
\hline Identify and select the $r$ & 9 & 4 & 10 & 17 & 30 & 0.757 & 3 \\
\hline $\begin{array}{l}\text { Use experienced resources procurement } \\
\text { team }\end{array}$ & 5 & 7 & 16 & 17 & 25 & 0.743 & 4 \\
\hline
\end{tabular}

The result of the study indicated that delivering the required quantity of material based on a schedule and purchasing material that complies with the specification was the highly important technique over the other with an RII value of 0.774 . Ordering only needed material is an essential method to overcome the challenges that can lead to material waste (Assem and Karima, 2011; Sasidharani and Jayanthi, 2015). Prevention of over-ordering is the most important strategy to 
handle material wastage (Ajayi et al., 2017). In addition, purchasing material that complies with the specification helps to reduce the quantity of material wastes, if not the material that did not fit with the specification is not acceptable and may be considered as waste if it was not resold or returned to the supplier. While proper procurement management systems ranked as the second technique in minimizing construction material wastes with an RII value of 0.771 . This is suggested as a key strategy in handling wastes of construction materials (Ajayi et al., 2017). The findings of this indicated that identification and selection of the right suppliers ( $\mathrm{RII}=0.757)$, as important strategies to reduce construction wastes from the construction sectors. To reduce construction wastes, identification and selection of the right material suppliers are devised measures for construction stakeholders as it helps to obtain quality materials at a right time (Aparna, 2017).

\section{Material handling and storage}

Table 4 represents material management strategies that relate to material storage and handling along with their overall rank. From the analysis result, proper storage of materials $(\mathrm{RII}=0.780)$ was found to be the key strategy in preventing breakage and deterioration of a material due to improper storage.

Table 4. Material storage and handling related minimization techniques of material wastes

\begin{tabular}{|c|c|c|c|c|c|c|c|}
\hline $\begin{array}{l}\text { Material waste minimization } \\
\text { techniques }\end{array}$ & 1 & 2 & 3 & 4 & 5 & RII & Rank \\
\hline Properly store materials & 0 & 10 & 15 & 17 & 28 & 0.780 & 1 \\
\hline $\begin{array}{l}\text { Train workers about how to handle } \\
\text { and install materials }\end{array}$ & 0 & 6 & 8 & 20 & 30 & 0.777 & 2 \\
\hline $\begin{array}{l}\text { Accurate inventory control } \\
\text { Carefully handle materials during }\end{array}$ & 0 & 10 & 15 & 19 & 26 & 0.769 & 3 \\
\hline work & 0 & 10 & 18 & 27 & 15 & 0.734 & 4 \\
\hline Mechanically handle materials & 5 & 11 & 15 & 17 & 22 & 0.714 & 5 \\
\hline Use adequate tools and equipment & 8 & 8 & 12 & 21 & 21 & 0.711 & 6 \\
\hline
\end{tabular}

Thus, each material should be properly stored at the project site (Assem and Karima , 2011). Adequate storage of material is the most important technique for reducing construction waste (Eze et al., 2016). Training workers about how to manage and install material is also rated as the second important technique from material storage and handling related techniques with an RII value of 0.777 . This is a strategic approach to handle waste issues by site workers (Adewuyi and Odesola, 2016; Endale Teferi, 2017). It serves to create awareness among workers, upgrade their knowledge about the essence of material wastage, and 
increase the technological accomplishment of their everyday activity. Accurate inventory control helps to protect construction material from wastage and is rated as the third highest important technique with RII 0.769 based on the analysis result of this work. According to Aparna (2017), inventory is the most vital technique to handle construction material wastes.

\section{Technology}

Here, by technology we mean adopting advanced construction systems as well as incorporating the product of technology directly in establishing construction projects. Technology has a major role in finishing the project within an estimated quantity of construction materials by preventing the issues that can lead to material wastes. In building construction projects, there are different types of modern construction systems and technology products used. According to Ali et al. (2019), modern construction methods are efficient practices to manage construction wastes. Table 5 shows different techniques that serve to control the generation of material wastes in building construction projects and their overall rank.

Table 5. Technology related minimization techniques of material wastes

\begin{tabular}{llllllll}
\hline Material waste minimization techniques & 1 & 2 & 3 & 4 & 5 & RII & Rank \\
\hline $\begin{array}{l}\text { Use prefabricated or off-site production of } \\
\text { components }\end{array}$ & 3 & 3 & 10 & 22 & 32 & 0.820 & 1 \\
$\begin{array}{l}\text { Adopt recycling technology to recycle } \\
\text { waste materials left-over on site }\end{array}$ & 0 & 7 & 14 & 27 & 22 & 0.783 & 2 \\
Adopt emerging technology product & 4 & 9 & 13 & 14 & 30 & 0.763 & 3 \\
Use recent plants and machinery & 4 & 11 & 15 & 15 & 25 & 0.731 & 4 \\
\hline
\end{tabular}

Based on the result of the current research, using prefabricated or off-site production of components was the most important strategy to control the issues that lead to the generation of material wastes on building sites and it ranked the first major technique with an RII value of 0.820. A recent study by Eze et al. (2016) identified that prefabricated and off-site construction components are significant strategy to prevent the factors leading to material waste. Adopting recycling technology to recycle waste materials left-over on-site ranked as the next important technique with an RII value of 0.783 . It was found to be the best technique to minimize material wastage in the construction site (Sasidharani and Jayanthi, 2015). In addition, the adoption of emerging technology products (rapid wall system, lightweight construction technology, composite construction material, and modular building components, etc.) in the construction project was 
the third important technique with a relative importance index value of 0.763 . The use of a modular design system and incorporation of a different emerging technology product is waste effective, easy to install, and can prevent onsite production wastes (Adewuyi and Odesola, 2016). It accelerates construction, improves quality, and reduces resources wastes (Wang et al., 2014).

\section{Legal or policy}

There is no specific policy that pertains to construction waste management in Ethiopia (Endale Teferi, 2017), but constitutional policy provisions and national environmental policies indirectly deal with the issue. Legal or policy-related strategies identified during this study were ranked to identify their importance level (Table 6).

Table 6. Legal or policy-related minimization techniques of material wastes

\begin{tabular}{|c|c|c|c|c|c|c|c|}
\hline Material waste minimization techniques & 1 & 2 & 3 & 4 & 5 & RII & Rank \\
\hline $\begin{array}{l}\text { Employ material waste management } \\
\text { officer }\end{array}$ & 0 & 5 & 10 & 27 & 28 & 0.823 & 1 \\
\hline $\begin{array}{l}\text { Incorporate policy of material waste } \\
\text { minimization plan }\end{array}$ & 2 & 6 & 9 & 25 & 28 & 0.803 & 2 \\
\hline $\begin{array}{l}\text { Provide scheduled training on material } \\
\text { waste minimization strategies for } \\
\text { construction firms }\end{array}$ & 0 & 4 & 18 & 22 & 26 & 0.800 & 3 \\
\hline $\begin{array}{l}\text { Establish strategies and guidelines for } \\
\text { use of recycled material }\end{array}$ & 6 & 6 & 8 & 21 & 30 & 0.777 & 4 \\
\hline $\begin{array}{l}\text { Obey instruction and work as per the } \\
\text { agreement }\end{array}$ & 2 & 11 & 8 & 21 & 28 & 0.777 & 5 \\
\hline Government environmental regulation & 4 & 7 & 15 & 16 & 28 & 0.763 & 6 \\
\hline Implement a safety program & 4 & 7 & 12 & 26 & 21 & 0.751 & 7 \\
\hline
\end{tabular}

From the analysis, employing a construction waste management officer at construction sites to handle waste issues had the highest importance with an RII of 0.823 . The appointment of a waste officer or manager on-site helps to control the factors leading to material wastes (Eze et al., 2016). The government should incorporate the policy of construction material waste minimization plan (CMWMP), which clearly shows the allowable amount and ways of disposal along with incentive and or penalty for the construction firms. For waste management strategy to be well adapted, at the policymaking level of CMWMP the legislative approach should consider the waste prevention strategies during the planning and construction stages (Ajayi et al., 2015). This approach prominently enables to engender on-site waste reduction in a construction project 
(Muhammad et al., 2020). Providing scheduled training on how to prevent and minimize material wastes for construction firms was the third important technique with an RII value of 0.800 . It helps to reduce the amount of material wastes generated from construction sites by creating awareness among site workers regarding the prevention method and severity associated with material wastes. Staff training and awareness creation of waste management are underlying strategies to control material waste (Assem and Karima, 2011; Eze et al., 2016).

\section{Planning and site management}

Adequate planning and site management have a major role in achieving different project requirements. Table 7 shows the types of techniques categorized under planning and site management along with their RII rank order.

Table 7. Planning and site management-related minimization techniques of material wastes

\begin{tabular}{|c|c|c|c|c|c|c|c|}
\hline Material waste minimization techniques & 1 & 2 & 3 & 4 & 5 & RII & Rank \\
\hline Appropriate waste management on si & 0 & 7 & 12 & 23 & 28 & 0.806 & 1 \\
\hline quant & 0 & 4 & 18 & 22 & 26 & 0.800 & 2 \\
\hline Effective and frequent site supervision & 3 & 9 & 9 & 20 & 29 & 0.780 & 3 \\
\hline $\begin{array}{l}\text { Provide incentives to motivate } \\
\text { personnel to minimize material } \\
\text { wastage }\end{array}$ & 6 & 6 & 8 & 21 & 30 & 0.777 & 4 \\
\hline $\begin{array}{l}\text { Use software for material planning and } \\
\text { scheduling }\end{array}$ & 4 & 7 & 11 & 21 & 27 & 列 & T \\
\hline $\begin{array}{l}\text { Properly inspect and check the quality } \\
\text { of materials on site }\end{array}$ & 1 & 12 & 13 & 14 & 30 & 0.771 & 5 \\
\hline material on the site & 5 & 6 & 8 & 26 & 25 & 0.771 & 5 \\
\hline Empl & 6 & 6 & 11 & 17 & 30 & 0.769 & 6 \\
\hline $\begin{array}{l}\text { Keep in mind the economic, social, and } \\
\text { environmental effect of wastage }\end{array}$ & 4 & 9 & 11 & 15 & 29 & 0.765 & 7 \\
\hline $\begin{array}{l}\text { Improve coordination among } \\
\text { stakeholders }\end{array}$ & 10 & 6 & 4 & 22 & 32 & 0.762 & 8 \\
\hline $\begin{array}{l}\text { Record and measure different streams } \\
\text { of waste }\end{array}$ & 6 & 7 & 10 & 22 & 25 & 0.751 & 9 \\
\hline
\end{tabular}

Appropriate waste management on-site $(\mathrm{RII}=0.806)$ held the first position in controlling the factors influencing to cause construction material wastes. It is essential for the achievement of building project objectives without material loss. It is suggested to be the most appropriate technique to control material wastage 
(Ali et al., 2019). It is also recognized as the critical method for achieving the required performance in construction projects (Forster, 2014).

Accurate measurement of the size and quantity of material on-site during work (RII $=0.800)$ took the second rank. It ensures effectiveness by avoiding overconsumption of material and errors during construction. According to Adewuyi and Odesola (2016), accurate measurement of materials during operations is an important technique for achieving construction activities without waste. Effective and frequent site supervision had an RII of 0.780. It is important to prevent the occurrence of wastage and take accurate actions on the project site (Eze et al., 2016).

\section{CONCLUSION}

The aim of this study was to determine material waste mitigation strategies for the reduction of material wastes in building construction sites in Addis Ababa, Ethiopia. In this study, it was found that employing material waste management officers in the construction site to handle waste issues could significantly reduce the generation of material wastes. In Ethiopia, it is not usual to assign professionals at every construction sites particularly to treat the waste issues. Established on the finding of this research to mitigate material wastes, it is essential to put a specific person to handle the factors that influence to cause material wastage. The survey proposes that the incorporation of prefabricated or off-site production of components is a strategy that can mitigate overall waste produced from a construction site. The study also gave evidence that appropriate waste management on-site significantly reduces material loss that occurs at the construction site. Materials could be managed properly from illegal dumping and mixing with soil, reusing the material for its designated purpose, identifying the recyclable material, and recycle on the project site.

The incorporation policy of material waste minimization plan also underlies waste management approach for achieving material waste effectiveness. Having adequate ground rules or policy regarding material wastage, for instance, if there are incentives provided for each waste effective building site and in other directions if there is punishment for those raising a vast quantity of waste beyond the allowable amount are all effective. In addition, policy regarding the amount and ways of disposal of waste and landfill fees for the material waste of the construction sector helps to assure the efficient minimization of material wastes. The study similarly showed that accurate measurement of the size and quantity 
of material on-site helps to minimize material wastage by reducing the item of work needed to rework, repair, and replace. Enhancing proper storage of material and effective and frequent site supervision could minimize material wastage.

In addition, offering scheduled training on material waste minimization strategies for construction firms regarding the severity and associated risks with it and the management practice has a great role in reducing waste. Moreover, designing standardized material dimension, training workers about how to manage and install materials, and obeying instruction and performing as per the agreement, and the employing experienced and sound design team, delivering the required quantity of material based on the time schedule, and purchasing material that complies with the specification are the critical strategies to prevent the generation of material wastes. In general, this study provided the most important measures that could be applied in building construction sites to handle material wastes. As the study was carried out within the context of Addis Ababa, further studies might be needed for the generalizability of the findings to other regions and construction sectors.

\section{ACKNOWLEDGMENTS}

The author wishes to recognize all organizations and individuals who contributed directly or indirectly to this research. Special thanks are forwarded to the participants who sacrificed their time during interviews and responded to the questionnaires.

\section{Conflict of interest}

The author declares no conflict of interest.

\section{REFERENCES}

Abarca-Guerrero, L., Maas, G and Twillert, H. (2017). Barriers and motivations for construction waste reduction practices in Costa Rica. Resource 6(4):69. doi:10.3390/resources6040069

Adewuyi, T.O and Odesola, IA. (2016). Material waste minimization strategies among construction firms in South-South Nigeria. International Journal of Sustainable Construction Engineering \& Technology 7(1): 11-29. http://penerbit.uthm.edu.my/ojs/index.php/IJSCET

Agyekum, K., Ayarkwa, J and Adjei-Kumi, T. (2013). Minimizing materials wastage in construction- A lean construction approach. Journal of Engineering and Applied Science $\mathbf{5}(1): 125-146$.

Ajayi, S.O. Oyedele, L.O., Bilal, M., Akinade, O.O., Alaka, A.H and Owolabi, H.A. (2017). Critical management practices influencing on-site waste minimization in construction projects. Waste Management 59: 330-339. http://dx.doi.org/10.1016/j.wasman.2016.10.040 
Ajayi, S.O and Oyedele, L.O. (2018). Waste-efficient materials procurement for construction projects: A structural equation modelling of critical success factors. Waste Management 75: 6069. https://doi.org/10.1016/j.wasman.2018.01.025

Ajayi, S.O., Oyedele, L.O., Bilal, M., Akinad, O.O., Alaka, H.A., Owolabi, H.A and Kadiri, O.K. (2015). Waste effectiveness of the construction industry: Understanding the impediments and requisites for improvements. Resources, Conservation and Recycling 102:101-112. http://dx.doi.org/10.1016/j.resconrec.2015.06.001

Ajayi, S.O., Oyedele, L.O., Akinad, O.O., Bilal, M., Alaka, H.A and Owolabi, H.A. (2017). Optimising material procurement for construction waste minimization: An exploration of success factors. Sustainable Materials and Technologies 11:38-46. doi: 10.1016/j.susmat.2017.01.001

Akadiri, P.O., Chinyio, E.A and Olomolaiye, P.O. (2012). Design of a sustainable building: A conceptual framework for implementing sustainability in the building sector. Journal of buildings 2:126-152. doi:10.3390/buildings2020126

Ali, T., Mert, G., Ferhat, K., Zhanar, B., Aiganym, S and Gulzat, S. (2019). A comprehensive construction and demolition waste management model using PESTEL and 3R for construction companies operating in Central Asia. Sustainability 11(6):1593. https://doi.org/10.3390/su11061593.

Amsale Markos. (2017). Concrete and concrete making materials wastage minimization in construction of housing project in Bole Bulbula site. M. Sc. Thesis, Addis Ababa Science and Technology university, Ethiopia.

Aparna, S.E. (2017). Factors affecting material management in construction industry. International Journal of Civil Engineering and Technology (IJCIET), 8(5): 869-880.

Asmara Seyoum. (2015). Managing and minimizing wastage of construction materials on selected public building projects in Addis Ababa. M.Sc. Thesis, Addis Ababa Institute of Technology, Ethiopia.

Assem , A.H and Karima, H. (2011). Material waste in the uae construction industry: main causes and minimization practices. Architectural Engineering and Design Management 7(4): 221-235. doi: 10.1080/17452007.2011.594576

Bekr, G.A. (2014). Study of the causes and magnitude of wastage of materials on construction sites in Jordan. Journal of Construction Engineering 2014:6. http://dx.doi.org/10.1155/2014/283298

CSA (Central Statistical Agency of Ethiopia). (2011). Report on contract construction survey. The Federal Democratic Republic of Ethiopia: Addis Ababa, Ethiopia.

Creswell, J.W. (2013). Qualitative inquiry and research design: Choosing among five approaches. $3^{\text {rd }}$ Edition, Sage, Thousand Oaks.

Dainty, A.R and Brooke, R.J. (2004) . Towards improved construction waste minimisation: A need for improved supply chain integration?. Structural Survey 22(1): 20-29.

Dajadian, S.A and Koch, D.C. (2014). Waste management models and their applications on construction sites. International Journal of Construction Engineering and Management 3(3): 9198. dio: $10.5923 /$ j.ijcem.20140303.02

Dania, A.A., Kehinde, J.O and Bala, K. (2007). A study of construction material waste management practices by construction firms in Nigeria. Caledonian University, Glasgow, Scottland (United Kingdom).

Daoud, A.A., Othman, A.A., Robinson, H and Bayat, A. (2018). Exploring the relationship between material procurement and waste minimization in the construction industry: the case of Egypt. International conference on sustainability, green building, environmental engineering and renewable energy (SGER2018), Kuala Lumpur, Malaysia. https//:openresearch.lsbu.ac.uk/item/86w20

DTIE, UNEP, Sustainable Consumption and Production Branch (2009). Buildings and climate change: A summary for decision makers. Paris, France. 
Endale Teferi (2017). Assessment of construction waste management and disposal strategies. The case of gelan condomminium construction project site. M. Sc. Thesis, $A$ ddis Ababa Science and Technology University, Ethiopia.

Enshassi, A., Al-Hallaq, K and Mohamed, S. (2006). Causes of contractors' business failure in developing countries: the case of Palestine. Journal of construction in developing countries, 11(2): 1-14.

Esin, T \& Cosgun, N. (2007). A study conducted to reduce construction waste generation in Turkey. Building and Environment 42: 1667-1674. doi:10.1016/j.buildenv.2006.02.008

Eze, E.C., Seghosime, R., Eyong, O.P and Loya, O.S. (2016). Assessment of materials waste in the construction industry: A view of construction operatives, tradesmen and artisans in Nigeria. The International Journal of Engineering and Science (IJES) 6(4): 32-47.

Forster, G. (2014). Construction site studies: Production administration and personnel. Elsevier, Routledge, Oxon.

Franco, M and Herbert, K. (2017). An investigation of waste management practices in the Zambian construction industry. Journal of Building Construction and Planning Research 5(1): 1-13. doi:10.4236/jbcpr.2017.51001.

Holt, G.D. (2014). Asking questions, analysing answers: Relative importance revisited. Construction Innovation 14(1): 2-16. https://doi.org/10.1108/CI-06-2012-0035

Husnain, A., Muhammad, Q., Muhammad, J and Hamza, F.G. (2017). Quantification of material wastage in construction industry of Pakistan: An Analytical Relationship between Building Types and Waste Generation. Journal of Construction in Developing Countries 22(2):19-34 doi:10.21315/jcdc2017.22.2.2

Kofoworola, O.F and Gheewala, S.H. (2009). Estimation of construction waste generation and management in Thailand. Waste Management 29: 731-738. doi:10.1016/j.wasman.2008.07.004

Lemlem Temesgen. (2016). Assessment of building construction efficiency; Case Study in Addis Ababa. M.Sc. Thesis, Jimma University, Jimma Institute of Technology, Ethiopia.

Lopes, J.P., Oliveira, R.A and Amreu, M.I. (2011). The construction industry and the challenges of the millennium development goals. Management and innovation for a sustainable built environment. Amsterdam, The Netherlands.

Lu, W and Yuan, H. (2011). A framework for understanding waste management studies in construction. Waste management 31(6):1252-60. doi: 10.1016/j.wasman.2011.01.018

Lu, W., Yuan, H., Li, J and Hao, J.J.L. (2011). An empirical investigation of construction and demolition waste generation rates in Shenzhen city, South China. Waste Management 31(4): 680-687. doi: 10.1016/j.wasman.2010.12.004

Muhammad, F.H., Ahmad, F.M.Z., Sasitharan, N., Rafikullah, D., Norhaslinda, A., Riduan, Y and Mustafa, K. (2020). The on-site waste minimization practices for construction waste. The 2 nd global congress on construction, material and structural engineering, IOP Publishing. doi:10.1088/1757-899X/713/1/012038

Ofori, G. (2015). Nature of the construction industry, its needs and its development: A review of four decades of research. Journal of Construction in Developing Countries 20(2): 115-135.

Olusanjo, O. F., Panos, G and Ezekiel, C. (2014). Quantitative analysis of the sources of construction waste. Journal of Construction Engineering, 2014:9. https://doi.org/10.1155/2014/651060

Osmani, M., Glass, J and Price, A.F. (2008). Architects' perspectives on construction waste reduction by design. Waste Management 28: 1147-1158. doi:10.1016/j.wasman.2007.05.011

Papargyropoulou, E., Preece, C., Padfield, R and Abdullah, A.A. (2011). Sustainable construction waste management in Malaysia: A contractor's perspective. Proceedings of the international conference on management and innovation for a sustainable built environment. 20-23 June 2011. Amsterdam, The Netherlands.

Prabhat, P and Meenu, M. (2015). Research methodology: Tools and techniques. Printed in Romania, Bridge Center, Romania, European Union. 
Roseline, I., Corina, J and Rudy, T. (2016). Factors influencing waste generation in the construction industry in Malaysia. Annual serial landmark international conferences on quality of life, Medan, Indonesia.

Sasidharani, B and Jayanthi, R. (2015). Material waste management in construction industries. International Journal of Science and Engineering Research (IJOSER) 3(5).

Sharma, A., Saxena, A., Sethi, M and Shree, V. (2011). Life cycle assessment of buildings: A review. Renewable and Sustainable Energy Reviews 15(1):871-875. https://doi.org/10.1016/j.rser.2010.09.008

Solis-Guzman, J., Marrero, M., Montes-Delgado, M.V and Ramirez-de-Arellano, A. (2009). A Spanish model for quantification and management of construction waste. Waste management 29(9): 2542-2548. https://doi.org/10.1016/j.wasman.2009.05.009

Tadesse Ayalew., Zakaria, D and Zoubeir, L. (2016). Assessment on performance and challenges of Ethiopian construction industry. Journal of Architecture and Civil Engineering 2(11): 01-11.

Tam, V.W. (2007). On the effectiveness in implementing a waste-management-plan method in construction. Waste Management 28: 1072-1080. doi:10.1016/j.buildenv.2006.10.003

Wang, C., Li, Z and Tam, V.W. (2014). Critical factors in effective construction waste minimization at the thedesign stage: A Shenzhen case study, China. Resources, Conservation and Recycling 82:1-7. http://dx.doi.org/10.1016/j.resconrec.2013.11.003

Wahab, A.B and Lawal, A.F. (2011). An evaluation of waste control measures in construction industry in Nigeria. African Journal of Environmental Science and Technology 5(3):246-254. http://www.academicjournals.org/AJEST 